\title{
INFORMATION SUPPORT FOR DECISION-MAKING DURING THE KOSOVO CRISIS
}

\author{
Todor KOBUROV
}

$\mathrm{T}$ The establishment of a Situation Center within the Ministry of Defense and a network of situation centers connecting various ministries and institutions is a part of the Crisis Management Concept and the draft Crisis Management Act. This is going to be a continuous process, which will substantially improve the organization of the activities of different institutions in case of a crisis and will increase the level of preparedness of the Republic of Bulgaria for integration in NATO and EU. ${ }^{1-3}$

At the beginning we have to make some notes on the meaning of the categories "crisis" and "crisis management". There are generally accepted definitions of "crisis" and "crisis management".

Crisis means "an event with the potential for largely spreading damage, requiring rapid response measures by the government, coordination between different organizations, and sometimes - extraordinary political decisions".

Crisis management means "a preliminary developed system of institutions and measures for prognostication of potential crises and for their prevention and handling."

Crises usually develop unexpectedly and sometimes resemble a time bomb. A crisis usually covers a large spectrum of negative events that may occur either on our own or on foreign territory.

\section{Bulgaria's contribution to crisis management}

The Republic of Bulgaria must develop crisis management capabilities and a system that can adequately react to a crisis situation. Being a small country, however, Bulgaria will not initiate or conduct a crisis management process on its own. Generally, it will cooperate with international organizations like NATO, EU, UN, OSCE or a coalition led by a large nation. 
It is not possible to initiate any crisis management process without constantly monitoring and analyzing the international situation - in the case of Bulgaria mainly in southeastern Europe. The goal is to try to anticipate, if possible, the emergence of crises or conflicts, evaluate requests for possible participation in peacekeeping, peace-enforcement, humanitarian and disaster-relief operations, advise the policy makers on the possibilities and risks for Bulgarian participation in such operations.

The institutions that are strongly involved in this kind of activity are the ministries of foreign affairs and defense, as well as the intelligence services.

\section{The role of the Ministry of Defense}

The Ministry of Defense should concentrate on the military aspects of the international situation. The existence of a Situation Center within the Ministry of Defense (SC-MoD) contributes to the capabilities for a coordinated reaction to military-political crises. In certain cases and according to law, it could also react to crises of non-military character (ethnic and religious contradictions, civil disobedience with massive show of violence, increased activity of local and transnational crime structures and terrorist organizations, massive refugee flows, etc.).

\section{SITUATION CENTER - MINISTRY OF DEFENSE}

Established with Council of Ministers' decision (25 March 1999)

Initially - part of the Temporary Inter-Departmental Situation

Center (IDSC) for monitoring and analyzing the Kosovo crisis

Directly subordinated to the Deputy Minister of Defense on Defense Policy and Planning

Developed within the Information and Analysis

Department of the Security Policy and Integration with NATO Directorate 
The Situation Center within the Ministry of Defense was established in implementation of decision \# 145/25 March 1999 of the Council of Ministers of the Republic of Bulgaria. It was designed as a segment of the Temporary InterDepartmental Situation Center (IDSC) monitoring and analyzing the Kosovo crisis and was directly subordinated to the Deputy Minister of Defense on defense policy and planning.

SC-MoD is developed within the Information and Analysis Section of the Security Policy and Integration with NATO Directorate of the Ministry of Defense. In case of a direct threat to the security of the Republic of Bulgaria the Defense Planning Directorate, the Bilateral Cooperation and Regional Issues Directorate and the Interoperability Center of the Ministry of Defense reinforce it.

\section{Functions of the Situation Center -MoD}

The main functions of SC-MoD are as follows:

- to inform and advise the leadership of the Ministry of Defense on the development of the international situation, on possible and emerging crises and conflicts, as well as to make proposals for decisions on crisis management and conflict prevention activities;

- to coordinate the efforts of the institutions within the framework of the Ministry of Defense for purposeful collection of information related to the conflict;

- to make conclusions and to produce reports, analyses, positions and proposals for military-political and military-technical measures to guarantee the Republic of Bulgaria's national security and, thus, to assist the Minister and the Deputy Ministers in elaborating the policy of the Ministry;

- to participate in the preparation of documents for the Minister and the Deputy Ministers of Defense for meetings of NATO, the European Union, and other international and regional forums;

- to prepare periodic documents on regional and international crises, risks of emerging conflicts, as well as on important international events, related to security and defense;

- to assist in carrying out information activities on the integration with NATO and other Euro-Atlantic and European structures, as well as on the military aspects of Bulgaria's security and defense policies (jointly with the Information and Public Relations Directorate);

- to maintain database on these issues together with the other departments of the Security Policy and Integration with NATO Directorate; 
- to conduct briefings for the leadership of the Ministry of Defense;

- to collect, summarize and analyze information on the development of the situation in Kosovo and the Federal Republic of Yugoslavia, the international situation related to the Kosovo conflict, as well as on possible and emerging crises and conflicts in South-Eastern Europe.

In order to establish an efficient system for information and analyses it is necessary to use the experience of NATO member-states and the Partnership for Peace countries. At present, the Ministry of Defense of the Republic of Bulgaria has established excellent relations with the Ministry of Defense of the Kingdom of the Netherlands. It is appropriate to further develop and improve these relations.

In its studies, the SC-MoD addresses the following issues:

- Existing and possible crises in South-Eastern Europe, and the Kosovo crisis in particular;

- $\quad$ NATO: integration in NATO, participation in the Euro-Atlantic Partnership Council, Membership Action Plan, Operation Capabilities Concept, Washington initiatives - OCC, TEEP, DCI, PMF;

- European Security and Defense: cooperation with EU, the development of the Common European Security and Defense Policy, Bulgaria's participation in EU-led peacekeeping and relief operations (Petersberg missions);

- Initiatives of other international organizations dealing with security and defense issues (the United Nations, the Organization for Security and Cooperation in Europe);

- Regional Security and Defense: Meetings of the Ministers of Defense of the countries of South-Eastern Europe, the Multinational Peace Force - SouthEastern Europe, the NATO Initiative on South-Eastern Europe, the Stability Pact on South-Eastern Europe /Working Table 3, sub-table 1 - Defense and Security/, the security and defense policies of the countries of the region, bilateral relations with the countries of the region.

SC-MoD is an important segment of the Crisis Management System on national level. Taking into account the experience of NATO member-states, and especially this of the smaller ones like the Netherlands, SC-MoD need to be staffed with highly qualified experts and analysts, and to be equipped with advanced communications means. SC-MoD has to dispose with resources for prognostication of crises, and for proposing actions for crises prevention and management. It should interact directly with and receive information from:

1. the General Staff of the Bulgarian Army and the Situation Center of the General Staff; 
2. the defense and military diplomatic representatives of the Republic of Bulgaria abroad;

3. the Military Information Service;

4. the Ministry of Foreign Affairs and other ministries;

5. non-governmental organizations and scientific institutions;

6. the mass media;

7. the Internet.

It should be possible that SC-MoD cooperates and exchanges information with partner institutions in both NATO member-states and countries participating in the Partnership for Peace Program.

\section{SITUATION CENTER - MINISTRY OF DEFENSE INTERACTION AND COOPERATION}

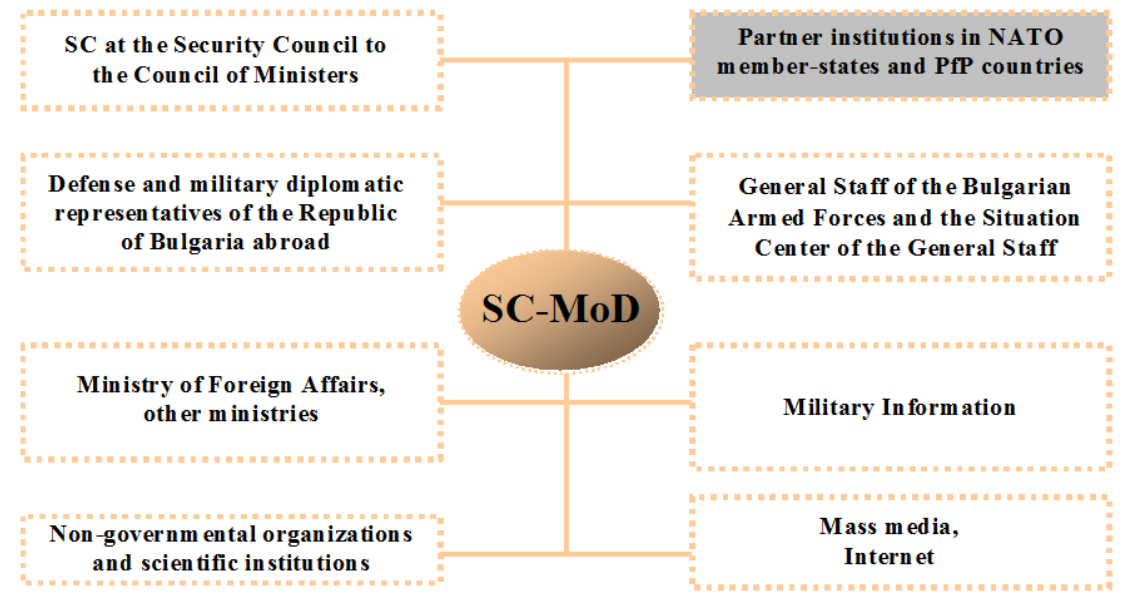

\section{The experience of the Kosovo crisis}

During the period 29 March - 20 June 1999 the General Reports on the Kosovo Crisis, produced by SC-MoD, had the following framework:

I. GENERAL INFORMATION;

II. RISKS FOR BULGARIA (political, humanitarian, economic, military, as well as internal security aspects and information campaign); 
III. CONCLUSIONS AND PROPOSALS (which risks could lead to a threat to the national security; what should be done in order to mitigate the risks; what should be done for reconstruction of damages as a consequence of already realized threats; what new risks may emerge during the development of the situation and how to prevent them).

The framework of the General Report on Kosovo was problem-oriented and was changed in the progress of the crisis depending on the circumstances. It was focussed on the following topics:

1. Positions of the various countries and international organizations.

2. Peace initiatives.

3. Impact on Bulgaria's goals and interests.

4. Relation to the process of Bulgaria's adherence to NATO and EU.

5. Development of the processes in NATO, the European Union, the United Nations and OSCE.

6. Evaluation of Republic of Bulgaria's position on a global and regional scale.

7. Humanitarian situation and refugees.

The SC-MoD General Report was submitted to the Minister of Defense and Deputy Ministers of Defense on defense policy and planning. It was also submitted to the Security Council at the Council of Ministers of the Republic of Bulgaria (where IDSC is attached) and was merged with the information submitted to the other teams of IDSC.

During the Kosovo crisis (the period from 29 March to 20 June 1999) the following information and analytical materials were produced:

A. GENERAL REPORTS - eighty-eight issues.

B. INFORMATION MATERIALS AND ANALYSES ON THE KOSOVO CRISIS - eleven issues on the following topics: the United Nations role; the condition of the FRY Army; possible scenarios of NATO operations; peace initiatives by 19 May plus chronology; reactions to President Milosevic's indictment by the Hague Tribunal; the Kosovo Liberation Army; strategic, economic and military consequences of the peace in Kosovo; problems facing the peace process; comparative analysis of the military annexes to the Rambouillet and Kumanovo Agreements; the UN Security Council resolution of 10 June (summary and analysis);

C. INFORMATION MATERIAL AND ANALYSES ON OTHER ISSUES eight issues on the following topics: Defense Capabilities Initiative; positions before the Washington NATO Summit; analyses of the 
Washington Summit documents (the Declaration, the Communiqué, the Strategic Concept, the Kosovo Declaration, assessments of Washington Summit of Belgium and of NATO Assistant Secretary General K.P. Kleiber, the WEU Action Plan "Europe of Defense").

\section{Conclusions, recommendations and proposals}

The Kosovo crisis showed the need to accelerate the establishment of a National Situation Center and a network of departmental situation centers for crisis management.

It is essential to establish a crisis management system based on the current legislation. The adopted Crisis Management Concept could, in principle, be the starting point for such a system. The process of legislative regulation in this field should continue with the adoption of a Crisis Management Act by the National Assembly.

The experience of the Kosovo crisis showed that the interaction between the departments, participating in IDSC, was unsatisfactory. One reason for that was the lack of a unified crisis management system. Another reason was the unclear definition of the functions and sharing of the responsibilities among various institutions - who is responsible for what and what could be expected from which institution. In many cases there was doubling of functions while one of the key issues for the national security - the political risks of the Kosovo crisis for the Republic of Bulgaria - remain practically uncovered.

The system of interaction between the institutions in case of a crisis must be worked out in advance, including clear definition of the functions and responsibilities. The principle framework of the reports and documents must also be prepared in advance allowing for changes in the course of the crisis depending on the circumstances.

In the establishment of the crisis management system serious attention must be paid to staff competence and technical equipment. In this respect, a "Vision of the Situation Center - Ministry of Defense" has to be elaborated.

\section{References:}

1. Velizar Shalamanov, "Analysis of the Threats and Synthesis of the Force Structure and Disposition," in Proceedings of $15^{\text {th }}$ AFCEA-Europe Symposium (Brussels: AFCEAEurope, October 1994), 59-63.

2. Stoicho Stoichev, Boris Buchinsky and Velizar Shalamanov, "Network of Situation Centers for Improved Management and Coordination," Military Journal 57, 6 (1994), $102-112$. 
3. Todor D. Tagarev, "The New Military Doctrine of The Republic of Bulgaria: Contribution of Communications and Information Technologies to Achieve National Security Objectives," in Proceedings of the C4/NCMC International Conference (Sofia, Bulgaria: June 1999), 7-17.

TODOR KOBUROV graduated political sciences at Sofia University in 1991. He has been working for the Ministry of Defense since 1995. He submitted his doctoral thesis in 1996 and became a doctor of political sciences at Sofia University. In the period March - September 2000 he took a specialized course in European Security on the "Count Baudisin" international program at the Peace Studies and Security Policy Institute of the Hamburg University. 